Volume 12, Nomor 2, November 2020, pp 223-232 Copyright (C) 2017

Jurnal Akuntansi, Program Studi Akuntansi, Fakultas Ekonomi, Universitas Kristen Maranatha. ISSN 2085-8698 | e-ISSN 2598-4977. http://journal.maranatha.edu

\title{
Chartered Accountant, ASEAN Economic Community and Industry 4.0
}

\author{
Sugeng Riadi ${ }^{1}$ \\ Business Management, Managerial Accounting Program, Politeknik Negeri Batam \\ (J1 Ahmad Yani, Batam City) \\ sugeng@polibatam.ac.id
}

\begin{abstract}
This study discusess the results of several studies about Chartered Accountant, ASEAN Economic Comunnity (AEC), Industry 4.0, Challenges and Opportunites. This research uses literature review approach that comparing and summarizing several literatures. Indonesian accountant (Chartered Accountant) is ready to face the AEC free market. Changes in the future both accounting science and accountants that is; cloud accounting data, accounting is influenced by the power of big data, the integration of traditional financial information into a modern system, accounting will be efficient and mobile and the role of accountant changes radically and fast. ASEAN Economic Comunnity (AEC) and industry 4.0 era can be opportunity and a threat to Indonesia, so Indonesian Accountant have to get ready with it.
\end{abstract}

Keywords: Chartered Accountant, Asean Economic Community, Industry 4.0

\begin{abstract}
Abstrak
Penelitian ini membahas hasil dari beberapa penelitian tentang Chartered Accountant, Masyarakat Ekonomi ASEAN (MEA), Industri 4.0, tantangan dan kesempatan. Penelitian ini menggunakan pendekatan studi pustaka yang membandingkan dan meringkas beberapa literatur. Akuntan Indonesia (Chartered Accountant) siap menghadapi pasar bebas MEA. Perubahan masa depan baik ilmu akuntansi maupun akuntan yaitu; data akuntansi cloud, akuntansi dipengaruhi oleh kekuatan big data, integrasi informasi keuangan tradisional ke dalam sistem modern, akuntansi akan menjadi efisien dan mobile dan peran akuntan berubah secara radikal dan cepat. Masyarakat Ekonomi ASEAN (MEA) dan era industri 4.0 dapat menjadi peluang sekaligus ancaman bagi Indonesia, sehingga Akuntan Indonesia harus bersiap menghadapinya.
\end{abstract}

Kata Kunci: Chartered Accountant, Masyarakat Ekonomi ASEAN, Industri 4.0 


\section{Introduction}

ASEAN agreed to develop an integrated region by forming an ASEAN community that is outward-looking, living in peace, stability and prosperity, caring for each other and bonded together in partnership. The agreement and hopes are contained in the ASEAN vision 2020. In 2003 the ASEAN countries formed ASEAN Economic Community (AEC) and began in 2015 with the aim of removing economic barriers and opening up mutual economics.

One of the collaborations in AEC is cooperation for financial services. The financial services profession is accountant. This is an opportunity and challenge for Indonesian accountant to compete with accountants from ASEAN member countries. One way to increase the professionalism and competitions opportunities, Indonesian Institute of Accountant designating the Indonesian Chartered Accountant (CA) as a professional accountant qualification in accordance with international standards guidelines. AEC provides opportunities for Indonesian accountant to open practices in ASEAN member countries.

Consequences of the agreement of AEC is free flow labor service including accountant service. Is Indonesian accountant ready to face that? According from (Khomsiyah \& Lindrianasari, 2017), the CA profession in Indonesia would face great challenges when skilled labor opens up in ASEAN and companies in Indonesia would to recruit educated and professionally certified from domestic or foreign countries.

The research from (Suttipun, 2014), stated to be able to compete and enable practice in AEC member countries, accounting professions must be achieve certain quality and competence, equip themselves with skills and knowledge in international accounting standards. How about Indonesian government to responded about that? The Indonesian government has issued regulations for the preparation of AEC. The regulation is PMK 25/PMK.01/2014. This regulation contains re-registration of accountants, professional accountant certification exams, accounting services, professional education for accountants, foreign accountants and professional organizations of accountants.

In addition to facing competition in the AEC, Indonesia has also begun to enter the industry 4.0. The World Economic Forum anticipates that Industry 4.0 would likely lead to a net loss of over 5 million jobs in 15 major developed and developing countries (Cann, 2016). The government of Indonesia is on implementing strategic steps determined based on the making Indonesia 4.0 road map. This effort was made to accelerate the realization of the national vision that has been set to take advantage of opportunities in the era of industry 4.0 (Satya, 2018). Industry 4.0 will have an impact on the accountant profession. An accountant must be aware of the development of the industry 4.0 by looking at the opportunities that exist (Rosmida, 2019).

The development in all industrial sectors in disruptive era impacts to the accounting rules and accounting profession. Since the digitalization plays an important part on the business, accounting will deal with more intangible assets, human resource and technology that might swift the concept of traditional accounting (Damayanti, 2019).

Sri Mulyani Indrawati, Indonesian Minister of Finance said within the next 5 years accountant service will be replaced by artificial intelegent and robots using the algorithm system (Financial Profession Expo at October, 2019). According to research conducted by the University of Oxford in 2015, 95 percent accountant lost their jobs because the machine took over the role of data and figure analysis (Triatmaja, 2019). The potential of technology to replace the role of the accounting profession is only a matter of 
time, the role of the accounting will be strategic and consultative (Rosmida, 2019).

The Industry 4.0 is changing how business operate. The professional accountant and auditors will need to adapt to remain relevant and thrive, education and training also needs to adapt (Hoffman, 2019). The accounting profession is predicted to be disrupted by technological developments, especially artificial intelligence (AI) and machine learning. Around 20-30 years ahead, routine and manual work what is usually done by an accountant will be taken over by the machine and robots (Triatmaja, 2019). Based on the background above, this study emphasizes the readiness and challenges facing accountants in the AEC and industry 4.0 by providing literature review. The purpose of this study is to conclude all relevant research to be followed up for all stakeholders such as accountant, government, companies and universities. From this conclusion, interested parties can find out what needs to be prepared to face AEC and industry 4.0.

\section{Literature Review}

\section{Chartered Accountant (CA)}

Indonesian Chartered Accountant is qualification of professionalism identity. This qualification is set to maintain and enhance public confidence in the accounting profession, provide protection to accounting services and prepare Indonesian accountant to face global challenges (Indonesian Institute of Accountant, www.iai.or.id)

IAI stated that of CA has function positions in managerial, operational, management control, accounting and stakeholder communication, public sector, academic and auditor. CA have main competence that is capability and competence in managing financial statement and decision making, integrity and professional ethics. In addition, CA has special competence that is able to prepare, presenting and evaluate financial statement with global standards, evaluate information system and internal control, evaluate corporate governance and social responsibility, applying individual and professional ethical values, integration of multidiscipline, tax policy, management, evaluate management accounting practice, evaluate strategic decision, leadership, continuoing of learning program, interactions and relationship with other.

\section{ASEAN Economic Community}

ASEAN Economic Community (AEC) is the agreements made with the aim to enable the economic integration among ASEAN countries (Upa, 2016). Three pillars support AEC is politics and security, economics and social culture (Khomsiyah \& Lindrianasari, 2017). In 2009, member of AEC agreed upon of set of mutual recognition arrangements (MRAs) with view to facilitating the free flow of skilled labour across the ASEAN region. According to (Suttipun, 2014), AEC has four main objectives that is building a free trade and service area, creating competitive advantage, sustainable economic development and economic integration including free trade area. A mutual recognition arrangements (MRAs) has been signed by several professional bodies including engineering, nursing, medical and accounting.

An MRA Framework on Accountancy Services was signed in 2009. The Framework provides for the free flow of accounting professional services between the ASEAN member countries. The agreements endeavours to establish mechanisms to achieve professional certification and standardization in each field by acknowledging the differences among the ASEAN countries in terms of the education, training, experience, and licensing requeriments for professional (Adhariani, Siregar, \& Yulius, 2019). 
There are many challenges facing the MRA implementation in the member countries. Some professional organizations like the accountants have commenced bilateral negotiations with counterpart bodies, taking into account the various differences in educational system, legal framework, institutional mechanism and socio-economic conditions (Aldaba, 2013).

\section{Industry 4.0}

Based on (Erol, Jäger, Hold, Ott, \& Sihn, 2016) the term of about artificial intelligence, supercomputing, robotics, big data, neuro-technological brain, biotechnology and genetic editing are matters relating to industry 4.0. (Baur \& Wee, 2015) explaine that some characteristic of industry 4.0, that is rise in data volumes, computational powers, connectivity, robotics and 3-D printing. According to (Wilkesmann \& Wilkesmann, 2018), industry 4.0 is comprehensive digitalization and linkage of production process.

Digitalization in all business operation and big data is key element of industry 4.0 (Hammer, Somers, Karre, \& Ramsauer, 2017). While (Burritt \& Christ, 2016) stated that of key concept underlying industry 4.0 are increased connectivity of networks using the internet of things and internet of services through cyber-physical systems. According to (Rosmida, 2019), perceived progress in industry 4.0 is internet, big data, cloud computing and machine learning.

Industry 4.0 is expected to influence accounting practices since the accountants can obtain previously unobtainable data in real time, raise data quality through greater accuracy and timeliness in improving data efficiency and data assurance as well as other decision-making purposes (Hart, 2017). Accountants will have the opportunity to be less involved with automated operations and focus more on big-picture strategies such as resource efficiency (Ghani \& Muhammad, 2019).
Accounting profession have to deal with the development of internet society when people do not need accountant as well as other professionals such as lawyer, doctor, teachers, and many more (Guthrie \& Parker, 2016).

\section{Research Method}

This research uses literature review approach that comparing and summarizing several literatures. A literature review distills the existing literature in a subject field; the objective of the literature review is to summarize the state of the art in that subject field (Rowley \& Slack, 2004). This study will analyze and interpreting the results of research on the relationship between Chartered Accountant, ASEAN Economic Community, Industry 4.0, challenges and future opportunities for accountants.

The criteria for the article chosen are articles that have a theme that is relevant to this study with various years. This research framework is that any research results that are displayed will be concluded and presented according to existing theories. This study uses the systematic literature review according to Kitchenham \& Charters (2007). The first step is planning about population, intervention, comparison, outcomes and context. The population is about Chartered Accountant, AEC and industry 4.0 journal and intervention about relationship, challenges and opportunities between these three topics. The second step is conducting about publication year, publication type, search stirng and selected studies. The type publication is journal and published in 2012-2019. Search string about the readness of accountant, companies and regulators in facing AEC and industry 4.0. The third step is reporting about introduction (state the purpose of the review), main body (result and discussion) and conclusion. 


\section{Result and Discussion}

\section{Chartered Accountant and ASEAN Economic Community}

The research of Upa (2016) about "Accountant and AEC", and she found the government of Indonesia and IAI already making preparations to face AEC, among them have issued regulations (PMK No.25/PMK.01/2014). However, to achieve this, the support of all Indonesian accountants is needed. The support of accountant is active participation in implementing regulations and involved in the development of accounting field. In addition to accountant support, university support is also needed. The universities to directing students to work as professional accountant, encouragement to continue their studies to the level professional accounting education, improve the quality of its graduates, student exchange program and also curriculum revision.

The research of Steelyana (2012) about " Preparing Indonesia skilled labor in the field of accounting, finance and capital market for AEC 205", and she found to host in our own country and be able to compete in the free market, especially the AEC 2015, skilled labor and professionals in field of accounting and finance in Indonesia should be increased. She also found that the education using system link and match with industries, understanding ASEAN cross culture and also support the government to make policies to increase the number of accountants.

Kusumasari (2014) researching about "Indonesian Institute of Accountant (IAI) Towards AEC 2015", and she found;

1. Indonesian Accountant is ready to enter the AEC 2015

2. In terms of organization, IAI has being a member of AFA and IFAC

3. Indonesia is ranked as number five as compared to other ASEAN countries in compliance to SMO (statement of member obligations) by IFAC
4. To become world-class body, IAI needs to improve quality assurance, socialize on international education standards, collaboration with IAPI, enhancing code of ethics as on IESBA and continuing convergence with IFRS

According to Triani, Diamastuti, \& Yanthi (2015) who researched about "The Readiness of Indonesian Accountant to Face AEC", she found that not all accountant profession are ready in facing this AEC free market. Public accountant in Indonesia expect the socialization of the MRA framework for accounting service. Public accountants are also required in providing their services to implement the Public Accountant Professional Standards (SPAP) which adopt the International Standards of Accountants (ISA). Some internal accountant not recognize themselves as internal accountant who must meet several existing qualifications, in improving their quality, so this internal accountant it will be difficult to compete in free market. The readiness of public sector accountants is sufficient in dealing with the AEC free market. They also tend to follow the existing certification with the aim of increasing their qualifications.

Khomsiyah \& Lindrianasari (2017) researching about "The influence of accounting education on the prospects of becoming a member of the Chartered Accountant profession: opportunities, challenges and expectations of Indonesia towards the AEC", she found that the reason behind the accountancy community to secure Chartered Accountant was dominated by the existence of challenges to continuously improve their intellectual abilities, this showed that some members of the accountant community in Indonesia are ready to face AEC 2015.

According to (Selvina, 2016), she research about "Indonesian accountant vs foreign accountant in Indonesian job competition as an effect of AEC 2015", and she found, first most Indonesian accountant in private sector do not get the training and 
program to develop their skill and to prepare AEC 2015. Secondly, Indonesian companies prefer Indonesian accountant to foreign accountants because of two reasons that is about salary and culture.

The research of Adhariani et al. (2019) about "Borderless with unequal opportunity? experts perspectives on AEC and impact on Indonesian accountant profession", and she found Indonesian management accountant are considered more prepared and able to work in AEC if they are reputable universities graduates and have worked in multinational companies. To face free flow of skilled labor, it needs of defensive and offensive approach, management accountant must have skills, softskill and technical experts that can be obtained from universities or training institutions.

Based on the results study above, the author summarizes that Indonesian accountant (Chartered Accountant) is ready to face the AEC free market. There are several things that must be done, so that Indonesian accountant can compete with other accountant from member countries, that is;

1. For accountant themselves

- Indonesian accountant must be registered as Chartered Accountant (international standards)

- Maintain the professional competence (participate in training, self-development or continuing learning program)

\section{Government}

- Make regulations that accommodate the accountant (PMK No.25/PMK.01/2014)

- Make and set policies for Indonesian accountant and for foreign accountant who will work in Indonesia.

3. Universities

- Curriculum revision

- $\quad$ Link and match with industries
- Prioritize expertise for students so they are ready to work when they graduate

4. Indonesian Institute of Accountant (IAI)

- Conduct continuing learning programs to maintain the competence of Indonesian accountant

- Increase CA membership participants throughout Indonesia

5. Companies or industries

- Friendly to new technology

- Training and certification for internal accountant and management accountant in their companies

\section{Accounting and Industry 4.0}

The research of Rojko (2017) about "Industry 4.0 concept: background and overview" in (Setiawan, 2019), state that accounting system that can contribute to supporting industry 4.0 is first, focus on things that cannot be replaced by technology (such as innovative, developing systems perspective, creatives, increasing the ability to work with data and decision making with data, able about change, complex problem solving, leadership skill and also people skill). Secondly is mastering in ERP (enterprise resource planning) and third is master in big data analysis.

According to Burritt and Christ in (Iswanto \& Wahjono, 2019), researching about "The impact of industry revolution 4.0 towards accounting science-essay", states that the four steps of accountants must take in the dealing with industry 4.0 is awareness, education, professional development and reaching out. While, (Rosmida, 2019) in the research about "Transforming the role of accountants in the era industry 4.0 and the challenges of society 5.0", she provided a strategy to face of the industry 4.0 that is; accountants has a certified accountant that is recognized nationally and internationally, make 
orientation goals according to professional abilities including being able to master information technology, make time management, always up to date, use software to maximize performance.

The research of Ghani \& Muhammad (2019) about "Industry 4.0: employers' expectations os accounting graduates and its implication on teaching and learning practices", and she found the expectations employers place on accounting students in the Industry 4.0 environment is set to change significantly, particularly in technologies used in the preparation, reporting and dissemination of financial information. Other than that, she found the replacement of physical human activities by machine, accounting practitioners see the need for accounting graduates to focus on continuous learning and education, particularly in acquiring knowledge and skills in IT.

Based on Meskovic, Garrison, Ghezal and Chen 2008 in Setiawan (2019), artificial intelegence-based technology is changing the role of management accountants that is enterprise performance management including business analysis, predictive accounting, management accounting methods, management of IT and share service as business, behavioral cost management and strategic planning. While, Gamage 2016 in Setiawan (2019), in the field of auditing, with big data auditor can perform data analysis so as to change the audit process at the transaction level and general ledger so that with the tools to be able to analyze better. Big data can also be applied in forensic accounting service. The service requires investigative knowledge and expertise to collect, analyze and evaluate evidence for interpretation of findings.

The research of (Khanh (2018) about "Impact of industrial revolution 4.0 (industry 4.0) to the accounting profession in Vietnam", she found that there were few accountant, auditor as well as career association and leaders of accounting and auditing organization focus on changing to adopt the industry 4.0 in their career. While, the Akhter \& Sultana (2018) found technology will not vanish this profession, rather reshaping with new and challenging responsibilities. Robotics automation and drones will replace some manual accounting job, artificial intelligence will change the role of CPAs but there is an expectation of increasing demand for skilled accountants.

Based on the results study above, the author summarizes that there are several things about accounting changes in the future both accounting science and accountants that is; cloud accounting data, accounting is influenced by the power of big data, the integration of traditional financial information into a modern system, accounting will be efficient and mobile and the role of accountants changes radically and fast.

\section{Challenges and Opportunities}

Asean Economic Comunnity (AEC) and industry 4.0 era can be opportunity and a threat to Indonesia. According data from the Finance Ministry's Accountants and Appraisers Supervisory Centre, In 2014 reveals that there were only less than 16.000 professional accountants while there are more than 226.000 companies in Indonesia that require accounting service Adhariani et al. (2019). This condition brings about opportunities and challenge for Indonesian accountant to tap the domestic and regional demand created by AEC.

According to Wakhyudi (2015) in Upa (2016) revealed that at the macro level, the population of ASEAN ranges from 600 million, of which 40 percent are Indonesian people. The large population can be an opportunity for Indonesia to face the AEC. This condition makes Indonesia the largest provider of human resources in ASEAN. Other than that, Wakhyudi (2015) in Upa (2016) stated that Indonesia is relatively high economic growth in recent years, Indonesia was ranked first as the country 
with the greatest investment flows in ASEAN, and was ranked second in Asia, after China. This condition indicates that the Indonesian economy is attracting the interest of market participants in ASEAN and Asia, but these opportunities can also be a threat, if Indonesia does not have a competitive human resource.

According to Gerd Leonhard in Iswanto \& Wahjono (2019), threats and opportunities of the industry 4.0, globally the era of digital industrialization produced 1-1,5 billion jobs throughout 2015-2025 due to the replacement of human positions with machines. Other than that, based on U.S Departement of Labor in Iswanto \& Wahjono (2019), estimated that $65 \%$ of elementary school students in the world will work in jobs that have never existed today. The era of digitalization has the potential to increase the net workforce to 2.1 million jobs by 2025 . There is potential for carbon emissions to be reduced by 26 billion metric tons from the industry (World Economic Forum).

The challenges of the industry 4.0 revolution can completely change the roles and standards of accountant. Iswanto \& Wahjon (2019), changes in the role of accountants is;

- Provides view or opinions about data

- Act as an advisor, whether as business advisor and also business partner

- Able to work together in mastering technology which includes data manipulation, working with robots and as a trainer in the field of artificial intelligence

- The accountant profession develops not only in the financial aspect but will extend to the non-financial reporting and data security aspects in cyberspace.

\section{Conclusions and Suggestion}

\section{Conclusions}

Based on the results of research from several researchers it can be conclude that Indonesian accountant (Chartered Accountant) must prepare to face the AEC and industry 4.0. Indonesian accountant must be registered as Chartered Accountant (international standards), maintain the professional competence (participate in training, self-development or continuing learning program). The government make and set policies for Indonesian accountant and for foreign accountant who will work in Indonesia. The universities must revise the curriculum, link and match with industries, prioritize expertise for students so they are ready to work when they graduate. The Indonesian Institute of Accountant (IAI), conduct continuing learning programs to maintain the competence of Indonesian accountant and increase CA membership participants throughout Indonesia. The companies or industries must friendly to new technology and training and certification for internal accountant and management accountant in their companies.

Industry 4.0 changes the roles of the accounting science and accountants that is; cloud accounting data, accounting is influenced by the power of big data, the integration of traditional financial information into a modern system, accounting will be efficient and mobile and the role of accountants changes radically and fast. ASEAN Economic Comunnity (AEC) and industry 4.0 era can be opportunity and a threat to Indonesia, so Indonesian Accountant have to get ready with it.

\section{Suggestion}

This study only concludes a few studies (literature review) and hopes that future research will be a direct survey about readiness, challenges and opportunities to universities, government and companies. 


\section{Reference}

Adhariani, D., Siregar, S. V., \& Yulius, R. (2019). Borderless with Unequal Opportunity? Experts' Perspectives on the ASEAN Economic Community and Impact on Indonesian Accountant Profession. The Qualitative Report, 24(5), 11471167.

Akhter, A., \& Sultana, R. (2018). Sustainability of Accounting Profession at the Age of Fourth Industrial Revolution. International Journal of Accounting and Financial Reporting, 8(4), 139.

Aldaba, R. M. (2013). ASEAN Economic Community 2015: Labor mobility and mutual recognition arrangements on professional services. Retrieved from

Baur, C., \& Wee, D. (2015). Manufacturing's next act. McKinsey \& Company, 6.

Burritt, R., \& Christ, K. (2016). Industry 4.0 and environmental accounting: a new revolution? Asian Journal of Sustainability and Social Responsibility, 1(1), 23-38.

Cann, O. (2016). Five million jobs by 2020: The real challenge of the fourth industrial revolution. Paper presented at the World Economic Forum. International Organisation for Public Private Cooperation, Geneva, Switzerland. Available from https://www. weforum. org/press/2016/01/five-million-jobsby-2020-the-real-challenge-of-thefourth-industrial-revolution.

Damayanti, C. R. (2019). Accounting and Its Challenges in the New Era. Paper presented at the Annual International Conference of Business and Public Administration (AICoBPA 2018).

Erol, S., Jäger, A., Hold, P., Ott, K., \& Sihn, W. (2016). Tangible Industry 4.0: a scenario-based approach to learning for the future of production. Procedia CiRp, 54(1), 13-18.

Ghani, E. K., \& Muhammad, K. (2019). Industry 4.0: Employers Expectations of Accounting Graduates and Its Implications on Teaching and Learning Practices. International Journal of Education and Practice, 7(1), 19-29.

Guthrie, J., \& Parker, L. D. (2016). Whither the accounting profession, accountants and accounting researchers? Commentary and projections. Accounting, Auditing \& Accountability Journal.

Hammer, M., Somers, K., Karre, H., \& Ramsauer, C. (2017). Profit per hour as a target process control parameter for manufacturing systems enabled by Big Data analytics and Industry 4.0 infrastructure. Procedia CiRp, 63, 715-720.

Hart, L. (2017). How industry 4.0 will change accounting? Newsletter. Journal of Accountancy, AICPA, USA. Available from https:// www. journalofaccountancy. com/newsletters/2017/sep/industry4-0-change-accounting. html.

Hoffman, C. (2019). Accounting and Auditing in the Digital Age. In.

Iswanto, A. C., \& Wahjono, W. (2019). PENGARUH REVOLUSI INDUSTRI 4.0 TERHADAP ILMU AKUNTANSI-ESAI. INFOKAM, 15(1).

Khanh, L. T. (2018). IMPACT OF INDUSTRIAL REVOLUTION 4.0 (INDUSTRY 4.0) TO THE ACCOUNTING PROFESSION IN VIETNAM. ICFE 2018, 346.

Khomsiyah, \& Lindrianasari. (2017). The influence of accounting education on the prospects of becoming a member of the chartered accountant profession: opportunities, challenges and expectations of Indonesia towards the ASEAN economic community. International Journal of 
Monetary Economics and Finance, 10(3-4), 257-269.

Kusumasari, L. (2014). Indonesian Institute of Accountants (IAI) Towards ASEAN Economic Community (AEC) 2015. Asia Pacific Journal of Accounting and Finance, 1-28.

Rojko, A. (2017). Industry 4.0 concept: background and overview. International Journal of Interactive Mobile Technologies (iJIM), 11(5), 77-90.

Rosmida, R. (2019). Transformasi Peran Akuntan dalam Era Revolusi Industri 4.0 dan Tantangan Era Society 5.0. Inovbiz: Jurnal Inovasi Bisnis, 7(2), 206-212.

Rowley, J., \& Slack, F. (2004). Conducting a literature review. Management research news.

Satya, V. E. (2018). Strategi Indonesia Menghadapi Industri 4.0. Info Singkat, 10(9), 19-24.

Selvina, M. (2016). Indonesian accountant vs foreign accountant in Indonesian job competition as an effect of Asean economic community 2015. International Journal of Business and Administrative Studies, 2(1), 1619.

Setiawan, A. (2019). Akuntansi 4.0: membayangkan Pendidikan Akuntansi dalam era Revolusi Industri 4.0 dengan Systems Thinking.

Steelyana, W. (2012). Preparing Indonesia skilled labor in the field of accounting, finance and capital market for ASEAN Economic Community 2015. Paper presented at the 1st International conference on business, International Relation and Diplomacy (ICOBIRD).

Suttipun, M. (2014). The readiness of Thai accounting students for the ASEAN Economic Community: An exploratory study. AJBA, 7(2).

Triani, N. N. A., Diamastuti, E., \& Yanthi, M. D. (2015). Kesiapan Profesi
Akuntan di Indonesia dalam Menghadapi MEA.

Triatmaja, M. F. (2019). Dampak Artificial Intelligence (AI) pada Profesi Akuntan.

Upa, V. A. (2016). Accountant and ASEAN Economic Community. ASIAN Journal of Management Sciences \& Education, 5(2), 2-15.

Wilkesmann, M., \& Wilkesmann, U. (2018). Industry 4.0-organizing routines or innovations? VINE Journal of Information and Knowledge Management Systems. 